\title{
LOOKING BEYOND FARM LOAN APPROVAL DECISIONS: LOAN PRICING AND NONPRICING TERMS FOR SOCIALLY DISADVANTAGED FARM BORROWERS
}

\author{
CESAR L. ESCALANTE* \\ Department of Agricultural and Applied Economics, University of Georgia, Athens, Georgia
}

ADENOLA OSINUBI

Department of Financial Planning, Housing, and Consumer Economics, University of Georgia, Athens, Georgia

CHARLES DODSON

Farm Service Agency, U.S. Department of Agriculture, Washington, D.C.

CARMINA E. TAYLOR

School of Geosciences, University of Edinburgh, Edinburgh, United Kingdom

\begin{abstract}
This study utilizes Farm Service Agency lending data to verify if previous racial and gender bias allegations still persist in more recent lending decisions. Beyond loan approval decisions, this study focuses on trends in direct loan packaging terms for approved single proprietorship farm borrowers. Results indicate that although no significant disparities were noted in loan amounts and maturities prescribed for various racial and gender minority groups, nonwhite male and female borrowers were usually charged higher interest rates than the others. Loan pricing differentials could have been the lenders' strategy for price management of borrowers' credit risks.
\end{abstract}

Keywords. Direct farm loans, gender bias, interest rate, loan amount, loan maturity, loan packaging, racial minority

JEL Classifications. Q14, J15, J16

\section{Introduction}

The lending industry's delivery of credit services has often been scrutinized for patterns of either preferential or unfair treatment of certain borrower groups. Recently, a string of lawsuits has been filed alleging racial and gender discrimination in the lending decisions made by a number of reputable firms. Among the well-publicized cases is Countrywide Financial Corporation, which agreed to pay $\$ 355$ million in 2011 after the Department of Justice validated a pattern of higher fees and rates charged to more than 200,000 minority

*Corresponding author’s e-mail: cescalan@uga.edu 
borrowers from 2004 to 2008 (Savage, 2011). In 2012, Wells Fargo was found guilty of the same offense committed against more than 30,000 minority borrowers during the period 2004-2009, in addition to steering more than 4,000 minority borrowers into costlier subprime mortgages while white borrowers with similar credit risk profiles were accommodated with regular loans (Savage, 2012). Honda also entered into settlement agreements with their minority customers and agreed to pay a settlement of $\$ 24$ million for charging higher interest rates to thousands of minority car buyers (Isidore, 2013; Meyers, 2015).

Beyond the civil cases, observers and analysts corroborate such trends and issues. The Consumer Federation of America pointed out that although women generally have higher credit scores than their male counterparts, they are $32 \%$ more likely to be charged higher interest rates than men with similar levels of creditworthiness (Tedeshi, 2007). Boehm, Thistle, and Schlottmann (2006) analyzed American Housing Survey data from 1991 to 2001 and found that African American and Hispanic borrowers paid mortgage rates that were higher than those charged to white borrowers by 20.63 and 11.80 basis points, respectively. Cheng, Lin, and Liu (2015) found that African American female borrowers were charged 26.5 basis points more in interest rates compared with white female clients in the same credit risk category.

In the farm sector, the U.S. Department of Agriculture (USDA) has been the plaintiff in several civil rights lawsuits filed by African Americans, Native Americans, Hispanic, and women farmers who had dealings with the USDA's Farm Service Agency (FSA), the government's lending arm to the farm sector. Among these cases, the Pigford v. Glickmann case of the African American farmers and the Keepseagle v. Vilsack lawsuit of the Native American farmers were upgraded into collective class action status in 1997 and 1999, respectively (Feder and Cowan, 2013).

The Pigford and Keepseagle cases ended in out-of-court settlements with the USDA in 1999 and 2011, respectively, whereby, as typical in such settlements, the defendant (USDA) was not required to admit guilt. In 2012, USDA Secretary Vilsack reached out to Hispanic and women farmers with offers for cash remunerations, in addition to tax and debt relief provisions, to affected farmers (May, 2012). The federal budget for all these settlement payments included more than $\$ 2$ billion allocated for African American farmers, $\$ 680$ million for Native American farmers, and $\$ 1.33$ billion earmarked for Hispanic and women farmers (Feder and Cowan, 2013).

Drawing on such controversies and developments, this article examines more recent loan transactions with minority farm borrowers under the FSA's lending programs. Specifically, this study provides evidence of whether the farmers' lawsuits and the significant financial strain on federal government finances have led to more equitable and fair lending decisions in recent years. The primary objective of this study is to present a comparative assessment of certain terms 
and conditions governing existing FSA loans obtained by borrowers with specific racial and gender attributes.

This article takes a different approach in verifying discriminatory trends in lending decisions made by loan officers. The conventional approach has usually focused on the loan application phase where the determinants of loan officers' decisions of approval or rejection are analyzed (Escalante, Epperson, and Raghunathan, 2009; Escalante et al., 2006). This study distinguishes itself by focusing on decisions made by loan officers after loan applications are approved. The parameters of interest in this study are the loan terms stipulated by lenders for borrowers with approved credit applications. Trends in the pricing and nonpricing components of the prescribed loan packaging terms for various racial and gender classes of farm borrowers will be analyzed using statistical and econometric techniques.

\section{Background and Motivations}

\subsection{Subjectivity in Loan Pricing and Nonpricing Decisions}

Even as financial institutions have credit risk assessment models designed to increasingly objectify the loan approval decision-making process (Miller and LaDue, 1989; Splett et al., 1994; Turvey, 1991), existing borrower appraisal systems still leave some room for the lending officers' subjective inputs. The influence of subjectivity also extends beyond approval-rejection decisions at the loan application stage. In discerning any irregularity in the lenders' stipulation of loan terms and conditions for approved loan accounts, decisions on setting interest rates usually draw immediate attention and scrutiny. The lenders' credit risk appraisal system could provide clues on deviant decisions by comparing interest rates charged to borrowing clients with similar credit risk profiles and ratings. Ideally, the appraisal system should classify such borrowers under the same loan pricing category.

Subjectivity, however, could be evident as well in other components of loan covenants outside the setting of interest rates. Among these could be the relationship between the amount of loan approved and the corresponding maturity (term) of the loan. More cautious lenders would decide to accommodate certain borrowers by approving loan amounts that are significantly below the original amount requested by the borrowers. In other instances, some lenders would prescribe a much shorter maturity to ensure the immediate recovery of the loan exposure to clients who do not rank highly in acceptability and preference (or are not on par with their most preferred and valued clients, but nonetheless exhibit some business potential). Shorter loan maturities could translate to serious liquidity problems, while the inadequacy of external funds (through smaller loan amounts) could derail a project's implementation and viability. The challenge then is to verify if a lender's cautious attitude 
reflects its usual stance when dealing with borrowers of similar credit risk profiles.

\subsection{Lending to Beginning Farmers}

The federal farm lending program administered by the USDA, through the FSA, provides direct and guaranteed loans as temporary sources of agricultural credit. The mission of the agency is to fill the gaps in the commercial credit market where creditworthy farmers, especially high-risk borrowers, are unable to obtain credit. Direct loans are usually the first line of assistance for these borrowers as these loan accommodations allow eligible borrowers to build a satisfactory borrowing record and eventually help borrowers graduate to commercial sector credit sources. Guaranteed credit is regarded as an intermediate step from direct loans to commercial credit in case graduation from the direct lending program to commercial credit cannot be completed, although some borrowers can immediately begin with guaranteed loans, bypassing the direct-loan stage.

The FSA's loan programs are primarily designed to assist underserved sectors of the farm economy experiencing difficulty in gaining access to borrowed funds through commercial lending channels. FSA borrowers must pass the "creditelsewhere test," which requires proof of previous denials of loan requests by commercial lenders. Through this requirement, the FSA has been regarded as the farmers' "lender of last resort" (Chite, 1998; Hanson, Delavan, and Power, 1996).

The FSA's Beginning Farmer program fulfills part of its commitment to assist underserved borrowers. The agency adopts a nonconventional credit risk assessment policy that defines "special borrower circumstances" normally unacceptable to other lenders. The lack of an acceptable historical and/or qualitative credit track record, regardless of a loan applicant's justification for deficiencies, is usually sufficient grounds for a commercial lender's denial of loan applications. The FSA's lending policies, however, contain provisions for special considerations in defining "historical credit delinquency" or "unacceptable credit history" for borrowers who do not have previous credit history (USDA-FSA, 1995) or who are unable to pay previous loans (or have delinquent payments) because of temporary circumstances such as job loss, loss of benefits or other income, and increase of living expenses attributable to illness, injury, or death (USDA-FSA, 1995, 1997). Under these special provisions, eligible beginning farmers have a greater chance of obtaining financial assistance from the agency.

\subsection{Lending to Minority Farmers}

A targeted accommodation of the credit needs of minority farmers, collectively labeled as socially disadvantaged (SDA) in terms of racial, ethnic, or gender minority status, is mandated by federal law. The Agricultural Credit Act of 1987 requires the secretary of agriculture to set annual participation rates at the county level for these farmers (The White House, 2000). This act defined these SDA 
borrowers to include racial or ethnic groups ${ }^{1}$ and women (Koenig and Dodson, 1999).

Subsequent federal laws (such as the Food, Agriculture, Conservation, and Trade Act of 1990 and a string of farm bills in the next decades) have upheld the mandate as Congress would usually set aside federal funds and set goals to accommodate beginning and SDA farmers and ranchers under the FSA's direct and guaranteed farm ownership and operating loan programs. The specific allocation or reservation of loanable funds from each year's federally appropriated FSA funds has been the government's client targeting scheme that ensures adequate federal farm credit access for SDA and beginning farmers and ranchers. Moreover, Congress also ruled that such farmers be given preference in acquiring land out of government inventory and other incentives in applying for conservation and rural development programs (National Sustainable Agriculture Coalition [NSAC], 2015).

\section{Data Sources and Analytical Methods}

This article utilizes a USDA-FSA national data set of farm borrowers under its direct loan program. The data set is a compilation of financial performance measures, demographic attributes, and approved loan terms of the FSA's existing direct borrowers from 2004 to 2014 operating single proprietorship businesses. ${ }^{2}$ In order to isolate the effects of highly volatile credit market conditions on credit decisions made by lenders, the data set excludes periods of economic recession (2008 and 2009) and extreme drought conditions (2012). After filtering the original data set to discard observations with missing data, especially on any of the three loan term measures (loan amount, interest rate, and maturity), a cross-sectional sample of 19,630 individual loan transaction observations was deemed usable for this analysis.

This study's analytical techniques consist of two phases. The first phase involves statistical pairwise comparisons of mean values of financial performance measures and approved loan terms among various racial and gender categories of borrowers. The second phase will employ seemingly unrelated regression (SUR) techniques using a system of equations consisting of separate, individual estimating equations for the three loan packaging elements (loan amount, pricing, and maturity) to discern the significant determinants of each loan term component.

1 The USDA recognizes that race and ethnicity are different classes. A Hispanic, for example, may or may not be a racial minority.

2 This approach addresses the issue of ascertaining the demographic attributes (such as gender, race, and age) of the borrowing firm's representative. In a single proprietorship, the sole business owner is properly designated as the borrower/firm representative. 


\section{Econometric Model Specification}

The FSA direct loan data set will be further analyzed using SUR techniques to discern any significantly different patterns in the formulation of terms and conditions stipulated for approved FSA loans. The model in this analysis uses the following SUR formulation (Moon and Perron, 2006):

$$
\begin{gathered}
y_{11}=\beta_{1}^{\prime} x_{11}+u_{11} \\
\vdots \\
y_{i j}=\beta_{j}^{\prime} x_{i j}+u_{i j},
\end{gathered}
$$

where $y_{i j}$ is the dependent variable, $x_{i j}$ is a $k_{i}$-vector of explanatory variables for observational unit $i, \beta$ represents the regression coefficients of the standardized variables, and $u_{i j}$ is an unobservable error term, where the double index $i j$ denotes the $i$ th observation of the $j$ th equation in the system (Gujarati and Porter, 2009; Moon and Perron, 2006). This equation can be expressed equivalently as follows (Fiebig, 2001; Green, 2012):

$$
y_{i j}=X_{i j} \beta_{j}+e_{i j} i=1, \ldots, N, j=1, \ldots, M .
$$

The distinct property of the SUR model is that it allows nonzero covariance between error terms $e_{i j}$ and $e_{i k}$ for a given individual $i$ across equations $j$ and $k$ :

$$
\begin{aligned}
& \operatorname{cov}\left(e_{i j}, e_{i k}\right)=\sigma_{i j}, \\
& \operatorname{cov}\left(e_{i j}, e_{i_{k}}^{\prime}\right)=0 \text { if } i \neq i^{\prime} .
\end{aligned}
$$

For the purposes of this study, the statistical software Stata's sureg function is used, which adopts an asymptotically efficient feasible generalized leastsquares algorithm developed in Green (2012). This formulation's generalized least squares estimator, which is designed to address heteroskedastic and autocorrelated disturbances, is portrayed as follows:

$$
\beta=\left[X^{\prime} \Omega^{\prime} X\right]^{-1} X^{\prime} \Omega^{-1} y=\left[X^{\prime}\left(\Sigma^{-1} \otimes I\right) X\right]^{-1} X^{\prime}\left(\Sigma^{-1} \otimes I\right) y .
$$

Three equations are developed to determine factors that influence a loan officer's decisions on specific components of a borrower's approved loan package. These components include the amount of loan approved, the stipulated fixed interest rate, and the maturity of the approved credit accommodation (in terms of number of years). The expanded formulations of the three separate equations model are presented as follows:

$$
\begin{aligned}
\text { loanamount }_{i 1} & =\beta_{1}^{\prime} \text { FINPER }_{i 1}+\beta_{2}^{\prime} \text { DEMO }_{i 1}+\beta_{3}^{\prime} \text { LOANCHAR }_{i 1}+e_{i 1}, \\
\text { interestrate }_{i 2} & =\beta_{1}^{\prime} \text { FINPER }_{i 2}+\beta_{2}^{\prime} \text { DEMO }_{i 2}+\beta_{3}^{\prime} \text { LOANCHAR }_{i 2}+e_{i 2}, \\
\text { loanmaturity }_{i 3} & =\beta_{1}^{\prime} \text { FINPER }_{i 3}+\beta_{2}^{\prime} \text { DEMO }_{i 3}+\beta_{3}^{\prime} \text { LOANCHAR }_{i 3}+e_{i 3} .
\end{aligned}
$$


In the these equations, the dependent variables are defined as follows: loanamount is the dollar amount of the borrower's loan obligation under the FSA direct loan program; interestrate is the contractual interest rate that the borrower is actually charged; loanmaturity is the number of years from approval that the borrower is expected to fully repay the loan. ${ }^{3}$

The independent variables include several financial performance (FINPER), demographic/structural (DEMO), and loan attribute (LOANCHAR) measures. FINPER variables include the usual components of lenders' credit scoring models used to appraise borrowers' credit risks (Splett et al., 1994). These measures are term debt coverage ratio (TDCR), operating expense ratio (OER), current ratio (CR), and debt-asset ratio (DAR). These variables capture significant determinants of a borrower's credit risk profile such as repayment capability (TDCR), financial efficiency (OER), liquidity (CR), and leverage conditions (DAR). Beyond their crucial roles in providing a quantifiable, objective basis for loan officers' decisions made in the loan approval/rejection phase, these measures can be recalled back to aid in the setting of more appropriate loan terms for approved direct loan accounts. Some lenders might use a composite index (derived from their credit scoring models) as the basis for decisions on setting loan terms, but in the absence of information on FSA's internally calculated credit scores for all their clients, this study instead considers a disaggregated credit risk assessment approach by looking at the specific influence of each credit scoring element on the loan terms stipulated for each loan account.

Among the demographic/structural (DEMO) variables included in all three estimating equations are a gender dummy identifier (Male Dum) that takes a value of 1 for male borrowers, ${ }^{4}$ a business-type dummy identifier (Single Prop Dum) that distinguishes single proprietorships from other business types, a racial class dummy variable (Non White Dum) that generally categorizes nonwhite borrowers comprising the minority class vis-à-vis the white farm borrowers, and the continuous variable Age to distinguish younger from older farm borrowers. In addition, a size indicator is included in this variable category by including a measure for the firm's revenues (Gross Revenues), which even the USDA Economic Research Service has used as a size measure.

Three more variables are included in the model to capture the specific characteristics of the FSA direct credit accommodation (LOANCHAR). These

3 The data set was compiled on a loan transaction basis, so in the event that a borrower has taken out an FSA direct loan more than once during the period 2009-2013, that borrower will account for more than one row observation in the data set. However, data on certain variables (such as financial performance measures) may not be identical for duplicate borrower entries as that information will be assessed at the time the account is evaluated and approved by the FSA.

4 The gender identifier variable corresponds to the official borrower of the account. In other words, the gender identifier for a corporate account corresponds to that firm's designated loan account representative, which most likely would be its corporate head. On the other hand, the gender identifier for single proprietorships is assumed to be that of the business owner/operator. 
are dummy variables to distinguish approved accounts under the FSA's beginning farmer program (Beg Farmer Dum), operating loan program (Optg Loan Dum), and refinancing accommodations (Refinance Dum). These identified loan accommodation types have distinct features compared with other loan accounts in terms of borrower credit risk profile (beginning vs. established farm businesses), loan purpose and extent of financing assistance (operating vis-à-vis farm ownership loans), and history of credit dealings with the FSA (refinancing accommodations). These considerations could be important determinants of loan terms prescribed by lending officers for specific direct loan accounts.

\section{Pairwise Statistical Difference Results}

Table 1 presents a tabulation of the means of selected financial performance measures (usually considered in lenders' credit risk appraisal or scoring models) for the entire sample as well as for several subsets of observations categorized according to their racial and gender classification. Tables 2 to 4 summarize the results of the statistical tests of significance of the mean value differences for the three loan terms (loan amount, effective interest rates, and loan maturity) conducted between pairs of borrower categories presented in a matrix format. The tables report the $t$-statistics for the pairwise tests conducted for each column-row pair.

\subsection{Comparative Farm Financial Conditions}

As can be gleaned from the summary in Table 1, nonwhite female borrowers operate smaller farms relative to the other borrower categories, including the male borrowers within the nonwhite category, in terms of total assets and gross farm revenues. In comparing the farms' liquidity conditions, nonwhite female borrowers have the lowest average current ratio, although the mean value of 2.16 for this group is still above the 2.0 norm. White female borrowers have the highest average operating expense ratio of 0.9084 , and nonwhite female borrowers' mean ratio is 0.8166 . These figures are significantly higher than entire data set's average of only 0.6200 . Notably, the pairwise differences in average TDCR values across the various borrower categories are statistically significantly different from zero. In other words, the repayment ability (TDCR) rates across most borrower categories are statistically indifferent from each other. ${ }^{5}$ Looking at the farmers' leverage decisions, pairwise comparisons of these ratios indicate a fairly homogeneous leverage structure across all borrower categories.

The trends of most of these results are actually consistent with those obtained in two earlier studies using a smaller, localized data set including direct FSA farm borrowers in Georgia provided by the FSA state office (Escalante, Epperson,

5 Detailed results of pairwise significance tests for all financial performance variable measures are available from the authors upon request. 
Table 1. Means of Selected Financial Performance Measures, Racial and Gender Borrower Categories, 2004-2014

\begin{tabular}{|c|c|c|c|c|c|c|c|c|c|}
\hline & All Farmers & Female & Male & White & Nonwhite & $\begin{array}{l}\text { White } \\
\text { Female }\end{array}$ & $\begin{array}{l}\text { White } \\
\text { Male }\end{array}$ & $\begin{array}{l}\text { Nonwhite } \\
\text { Female }\end{array}$ & $\begin{array}{l}\text { Nonwhite } \\
\text { Male }\end{array}$ \\
\hline Total assets $(\$)$ & 518,935 & 315,446 & 544,419 & 537,924 & 315,159 & 320,682 & 564,155 & 274,948 & 322,226 \\
\hline Current ratio & 3.02 & 2.84 & 3.06 & 2.98 & 3.07 & 2.90 & 2.87 & 2.16 & 3.16 \\
\hline Debt-asset ratio & 1.30 & 0.69 & 1.38 & 1.34 & 0.90 & 0.61 & 1.43 & 1.33 & 0.83 \\
\hline Operating expense ratio & 0.6200 & 0.8582 & 0.5891 & 0.6034 & 0.7945 & 0.8637 & 0.5710 & 0.8166 & 0.7904 \\
\hline Term debt coverage ratio & 2.31 & 1.74 & 2.39 & 1.96 & 3.06 & 1.69 & 2.00 & 2.12 & 3.79 \\
\hline Number of borrowers & 19,630 & 2,254 & 17,376 & 17,927 & 1,703 & 1,987 & 15,940 & 267 & 1,436 \\
\hline
\end{tabular}

aThe data set excludes observations for the years 2008, 2009, and 2012.

Source: U.S. Department of Agriculture Direct Loan Program Dataset (provided by C. Dodson). 
Table 2. Pairwise Statistical Mean Difference Two-Tailed $t$-Test Results ${ }^{\mathrm{a}}$ for Approved Loan Amounts, 2004-2014 Farm Service Agency Direct Loans' Racial and Gender Borrower Categories ${ }^{\mathrm{b}}$

\begin{tabular}{|c|c|c|c|c|c|c|c|c|c|}
\hline Variables/Borrower Categories & All Farmers & Female & Male & White & Nonwhite & $\begin{array}{l}\text { White } \\
\text { Female }\end{array}$ & $\begin{array}{l}\text { White } \\
\text { Male }\end{array}$ & $\begin{array}{l}\text { Nonwhite } \\
\text { Female }\end{array}$ & $\begin{array}{l}\text { Nonwhite } \\
\text { Male }\end{array}$ \\
\hline Approved loan amount, $\$$ & 79,023 & 51,964 & 82,534 & 79,590 & 69,478 & 52,701 & 84,480 & 46,475 & 60,929 \\
\hline All & $\mathbf{a}$ & & & & & & & & \\
\hline Female & 17.19 & 口 & & & & & & & \\
\hline Male & $(4.25)$ & $(19.24)$ & $\mathbf{\square}$ & & & & & & \\
\hline White & $(0.69)$ & $(17.43)$ & 3.48 & $\mathbf{\square}$ & & & & & \\
\hline Nonwhite & 5.38 & $(7.84)$ & 7.30 & 5.66 & $\mathbf{\square}$ & & & & \\
\hline White female & 15.64 & $(0.34)$ & 17.59 & 15.88 & 7.25 & $\mathbf{\square}$ & & & \\
\hline White male & $(6.44)$ & $(20.32)$ & $(2.23)$ & $(5.63)$ & $(8.34)$ & $(18.61)$ & $\mathbf{\square}$ & & \\
\hline Nonwhite female & 8.41 & 1.34 & 9.30 & 8.55 & 5.50 & 1.50 & 9.79 & $\mathbf{\square}$ & \\
\hline Nonwhite male & 9.31 & $(3.78)$ & 11.05 & 9.56 & 3.41 & $(3.37)$ & 11.99 & $(3.40)$ & $\square$ \\
\hline
\end{tabular}

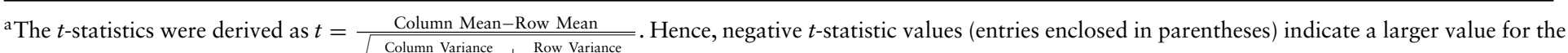
$\sqrt{\frac{\text { Column Variance }}{\text { Column Sample Size }}+\frac{\text { Row Variance }}{\text { Row Sample Size }}}$

column category relative to the value for the row category. Bold entries indicate significant $t$-test results at least at the $90 \%$ confidence level (i.e., $t$-statistic result greater than 1.645).

b The data set excludes observations for the years 2008, 2009, and 2012. 
and Raghunathan, 2009; Escalante et al., 2006). In these studies, the overall trends indicate that white borrowers usually operate significantly larger (total assets and gross farm revenues) and more liquid (current ratio) farm operations. Among gender classes, farms operated by male farmers usually are significantly larger (only in terms of gross farm revenues), but female-operated farms have significantly lower leverage (debt-asset) ratios.

\subsection{Comparative Lending Terms}

Results for the pairwise comparisons of mean loan term parameters (Tables 23 4) produce interesting trends. Male borrowers received significantly larger direct loans than their female counterparts. This trend is verified with gender class comparisons in both white and nonwhite racial categories. Nonwhite female farmers registered the lowest average direct loan amount, although this amount is statistically equivalent to the average figure calculated for white female farmers. Notably, this equivalence of loan amounts persists even if white female farmers operate significantly larger operations (both in terms of gross revenues and assets) than nonwhite female farmers (Table 1).

In terms of loan pricing, male borrowers are charged significantly higher interest rates on average compared with the rates stipulated for female borrowers. This trend persists among white males and females, but not among nonwhite farmers as the male and female subcategories in this group have statistically equivalent loan rates. In terms of general racial categories, the average interest rate on loans granted to nonwhite farmers is significantly higher than the rate calculated for white farmers. This trend is verified among the racial-gender subgroupings among both white and nonwhite farmers. Specifically, nonwhite male and female farmers both have significantly higher interest rates than their male and female counterparts, respectively, among white farmers. These rate differentials could have been determined by other factors as earlier comparisons reveal that the repayment capability, liquidity, and leverage measures are statistically equivalent across all borrower categories (Table 1).

The analysis of the prescribed repayment terms also yields interesting trends. Male borrowers enjoy longer loan terms than their female counterparts, but white and nonwhite borrowers have statistically equivalent average loan maturities. The loan terms prescribed for nonwhite male and female borrowers are also equivalent to the terms enjoyed by their respectively gender counterparts among white borrowers. Only white male and female borrowers have statistically different loan terms, with the former category allowed to repay over a longer period of time.

When all three loan terms are analyzed collectively, decisions on setting interest rates should ideally be coordinated with loan amount and maturity decisions. In other words, a higher interest rate could be offset by a relatively longer maturity and/or smaller loan amount in order to reduce the borrower's burden to produce larger periodic loan servicing funds. In this analysis, the 
Table 3. Pairwise Statistical Mean Difference Two-Tailed $t$-Test Results ${ }^{a}$ for Approved Loan Terms, 2004-2014 Farm Service Agency Direct Loans' Racial and Gender Borrower Categories ${ }^{\mathrm{b}}$

\begin{tabular}{|c|c|c|c|c|c|c|c|c|c|}
\hline Variables/Borrower Categories & All Farmers & Female & Male & White & Nonwhite & $\begin{array}{l}\text { White } \\
\text { Female }\end{array}$ & $\begin{array}{l}\text { White } \\
\text { Male }\end{array}$ & $\begin{array}{l}\text { Nonwhite } \\
\text { Female }\end{array}$ & $\begin{array}{l}\text { Nonwhite } \\
\text { Male }\end{array}$ \\
\hline Loan interest rate, $\%$ & 3.50 & 3.45 & 3.51 & 3.49 & 3.66 & 3.42 & 3.49 & 3.64 & 3.66 \\
\hline All & $\mathbf{a}$ & & & & & & & & \\
\hline Female & 1.62 & $\mathbf{\square}$ & & & & & & & \\
\hline Male & $(0.43)$ & $(1.81)$ & $\mathbf{\square}$ & & & & & & \\
\hline White & 0.92 & $(1.17)$ & 1.32 & $\mathbf{\square}$ & & & & & \\
\hline Nonwhite & $(4.24)$ & $(4.45)$ & $(4.03)$ & $(4.62)$ & $\mathbf{\square}$ & & & & \\
\hline White female & 2.22 & 0.55 & 2.40 & 1.79 & 4.82 & $\mathbf{\square}$ & & & \\
\hline White male & 0.41 & $(1.40)$ & 0.81 & $(0.47)$ & 4.38 & $(2.00)$ & $\mathbf{\square}$ & & \\
\hline Nonwhite female & $(1.63)$ & $(2.15)$ & $(1.54)$ & $(1.81)$ & 0.24 & $(2.41)$ & $(1.71)$ & $\mathbf{a}$ & \\
\hline Nonwhite male & $(3.98)$ & $(4.29)$ & $(3.78)$ & $(4.33)$ & $(0.08)$ & $(4.65)$ & $(4.10)$ & $(0.29)$ & $\mathbf{\square}$ \\
\hline
\end{tabular}

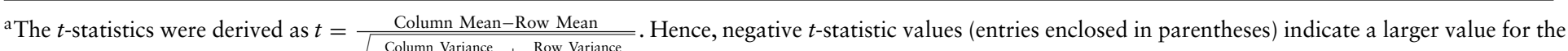
$\sqrt{\frac{\text { Column Variance }}{\text { Column Sample Size }}+\frac{\text { Row Variance }}{\text { Row Sample Size }}}$

column category relative to the value for the row category. Bold entries indicate significant $t$-test results at least at the $90 \%$ confidence level (i.e., $t$-statistic result greater than 1.645).

b The data set excludes observations for the years 2008, 2009, and 2012. 
Table 4. Pairwise Statistical Mean Difference Two-Tailed $t$-Test Resultsa for Approved Maturities, 2004-2014 Farm Service Agency Direct Loans' Racial and Gender Borrower Categories ${ }^{\mathrm{b}}$

\begin{tabular}{|c|c|c|c|c|c|c|c|c|c|}
\hline Variables/Borrower Categories & All Farmers & Female & Male & White & Nonwhite & $\begin{array}{l}\text { White } \\
\text { Female }\end{array}$ & $\begin{array}{l}\text { White } \\
\text { Male }\end{array}$ & $\begin{array}{l}\text { Nonwhite } \\
\text { Female }\end{array}$ & $\begin{array}{l}\text { Nonwhite } \\
\text { Male }\end{array}$ \\
\hline Maturity, years & 11.60 & 10.88 & 11.70 & 11.58 & 11.85 & 10.83 & 11.67 & 11.21 & 11.97 \\
\hline All & $\mathbf{\square}$ & & & & & & & & \\
\hline Female & 3.75 & $\mathbf{\square}$ & & & & & , & & \\
\hline Male & $(0.97)$ & $(4.20)$ & $\mathbf{\square}$ & & & & & & \\
\hline White & 0.24 & (3.61) & 1.19 & $\mathbf{\square}$ & & & & & \\
\hline White female & 3.74 & 0.17 & 4.17 & 3.61 & 3.47 & $\mathbf{\square}$ & & & \\
\hline White male & $(0.71)$ & $(4.05)$ & 0.24 & $(0.92)$ & 0.76 & $(4.03)$ & $\mathbf{\square}$ & & \\
\hline Nonwhite female & 0.79 & $(0.62)$ & 0.97 & 0.74 & 1.18 & $(0.69)$ & 0.93 & $\mathbf{\square}$ & \\
\hline Nonwhite male & $(1.46)$ & (3.61) & $(1.07)$ & $(1.54)$ & $(0.37)$ & $(3.66)$ & (1.17) & (1.37) & $\square$ \\
\hline
\end{tabular}
a The $t$-statistics were derived as $t=\frac{\text { Column Mean-Row Mean }}{\sqrt{\frac{\text { Column Variance }}{\text { Column Sample Size }}+\frac{\text { Row Variance }}{\text { Row Sample Size }}}}$. Hence, negative $t$-statistic values (entries enclosed in parentheses) indicate a larger value for the

column category relative to the value for the row category. Bold entries indicate significant $t$-test results at least at the $90 \%$ confidence level (i.e., $t$-statistic result greater than 1.645).

${ }^{\mathrm{b}}$ The data set excludes observations for the years 2008, 2009, and 2012 
trends among male and nonwhite borrowers reflect the interest rate-loan maturity linkage as these categories are charged relatively higher interest rates but enjoy longer maturities. Nonwhite male and female borrowers are charged significantly higher interest rates but are given loan maturities equivalent to those prescribed for their gender counterparts among white borrowers. These issues will be further verified under an econometric framework designed to validate, among other issues, whether or not racial and gender factors influence the lenders' decisions on each of the loan term stipulations.

\section{Seemingly Unrelated Regression Results}

Table 5 reports the results of the SUR model for the different estimating equations that make up the system of equations. ${ }^{6}$ The justification for the relevance of the SUR model to this data set has been established by the result of the Breusch-Pagan (BP) test of independence. The BP test produced a significant $\chi^{2}$ statistic that suggests that the null hypothesis of independence can be rejected. Given this rejection, the BP test result suggests that the error terms of the three separate estimating equations are contemporaneously correlated. Hence, this provides justification for the application of the SUR model to the three defined estimating equations that can now be collectively combined as a system of equations under an SUR framework.

All three estimating models have significant $\chi^{2}$ statistics, and their $R^{2}$ values range from $16.67 \%$ to $65.68 \%$. These results suggest that these models have adequate explanatory power. Results for the three equations are discussed separately in the following subsections.

\subsection{Loan Amount Decisions}

The racial and gender category variables (Female Dum and Non White Dum) have significant negative coefficients and thus suggest that smaller loan amounts were approved for these farmers. This contention is supported by the significant positive coefficient of the business-size variable, Gross Revenues, indicating that larger loan amounts are associated with larger businesses. Interestingly, farms operated by female and nonwhite farmers are usually significantly smaller operations compared with those operated by male and white farmers, respectively (Table 1). The association between the amount of loan approved and business size, however, could not be clearly established as no data on the amount of loan requests are available for this study.

All three loan attribute variables produced significant coefficients. The results indicate that decisions to disburse larger loan amounts favor farmer borrowers in the Farm Ownership and Beginning Farmer loan programs, as well as

6 Diagnostic tests conducted on the separate estimating equations of the SUR model indicate the absence of multicollinearity as variance inflation factors obtained for all regressors were below 10 . 
Table 5. Seemingly Unrelated Regression Results, Farm Service Agency Direct Loans, 2004$2014^{\mathrm{a}}$

\begin{tabular}{|c|c|c|c|}
\hline \multirow[b]{2}{*}{ Explanatory Variables } & \multicolumn{3}{|c|}{$\begin{array}{l}\text { Coefficient Results for Various Loan Term Models } \\
\text { (standard errors are in parentheses) }\end{array}$} \\
\hline & Loan Amount & Interest Rate & Loan Maturity \\
\hline Intercept & $\begin{array}{l}49,274.90^{* * *} \\
(2,698.20)\end{array}$ & $\begin{array}{l}5.20^{* * *} \\
(0.03)\end{array}$ & $\begin{array}{l}23.30^{* * *} \\
(0.16)\end{array}$ \\
\hline \multicolumn{4}{|c|}{ A. Financial performance measures } \\
\hline Term debt coverage ratio & $\begin{array}{l}-5.05 \\
(10.26)\end{array}$ & $\begin{array}{l}1.54 \mathrm{e}-05 \\
(1.52 \mathrm{e}-04)\end{array}$ & $\begin{array}{l}8.70 \mathrm{e}-4 \\
(7.92 \mathrm{e}-04)\end{array}$ \\
\hline Operating expense ratio & $\begin{array}{l}0.33 \\
(0.63)\end{array}$ & $\begin{array}{l}-1.20 \mathrm{e}-05 \\
(9.31 \mathrm{e}-06)\end{array}$ & $\begin{array}{l}-1.11 \mathrm{e}-04^{* *} \\
(4.86 \mathrm{e}-05)\end{array}$ \\
\hline Current ratio & $\begin{array}{l}0.23^{* * *} \\
(0.06)\end{array}$ & $\begin{array}{l}-4.22 \mathrm{e}-06^{* * *} \\
(8.65 \mathrm{e}-07)\end{array}$ & $\begin{array}{l}-1.12 \mathrm{e}-05^{* *} \\
(4.51 \mathrm{e}-06)\end{array}$ \\
\hline Debt-asset ratio & $\begin{array}{l}0.06 \\
(0.08)\end{array}$ & $\begin{array}{l}-1.14 \mathrm{e}-06 \\
(1.20 \mathrm{e}-06)\end{array}$ & $\begin{array}{l}1.11 \mathrm{e}-05^{*} \\
(6.26 \mathrm{e}-06)\end{array}$ \\
\hline \multicolumn{4}{|c|}{ B. Structural and demographic attributes } \\
\hline Gross Revenues & $\begin{array}{l}0.08^{* * *} \\
(0.00)\end{array}$ & $\begin{array}{l}-2.00 \mathrm{e}-09 \\
(2.72 \mathrm{e}-08)\end{array}$ & $\begin{array}{l}5.19 \mathrm{e}-08 \\
(1.42 \mathrm{e}-07)\end{array}$ \\
\hline Non White Dum & $\begin{array}{l}-8,905.20^{* * *} \\
(2,111.92)\end{array}$ & $\begin{array}{l}0.09^{* * *} \\
(0.03)\end{array}$ & $\begin{array}{l}-0.06 \\
(0.16)\end{array}$ \\
\hline Female Dum & $\begin{array}{l}-14,596.22^{* * *} \\
(1,879.15)\end{array}$ & $\begin{array}{l}0.02 \\
(0.03)\end{array}$ & $\begin{array}{l}-0.11 \\
(0.15)\end{array}$ \\
\hline Age & $\begin{array}{l}34.57 \\
(42.49)\end{array}$ & $\begin{array}{l}0.01^{* * *} \\
(6.29 \mathrm{e}-04)\end{array}$ & $\begin{array}{l}0.03^{* * *} \\
(3.28 \mathrm{e}-03)\end{array}$ \\
\hline \multicolumn{4}{|l|}{ C. Loan attributes } \\
\hline Beg Farmer Dum & $\begin{array}{l}34,192.62^{* * *} \\
(1,213.57)\end{array}$ & $\begin{array}{l}-0.43^{* * *} \\
(0.02)\end{array}$ & $\begin{array}{l}-1.60^{* * *} \\
(0.09)\end{array}$ \\
\hline Optg Loan Dum & $\begin{array}{l}-2,153.89^{* *} \\
(1,268.88)\end{array}$ & $\begin{array}{l}-2.47^{\text {*** }} \\
(0.02)\end{array}$ & $\begin{array}{l}-16.47^{* * *} \\
(0.10)\end{array}$ \\
\hline Refinance Dum & $\begin{array}{l}19,174.97^{* * *} \\
(1,760.61)\end{array}$ & $\begin{array}{l}-0.01 \\
(0.03)\end{array}$ & $\begin{array}{l}-0.71^{* * *} \\
(0.14)\end{array}$ \\
\hline \multicolumn{4}{|l|}{ Models' statistics } \\
\hline $\begin{array}{l}\chi^{2} \\
R^{2}\end{array}$ & $\begin{array}{l}3,070^{* * *} \\
0.1667\end{array}$ & $\begin{array}{l}18,621^{* * *} \\
0.5481\end{array}$ & $\begin{array}{l}29,382^{* * *} \\
0.6568\end{array}$ \\
\hline $\begin{array}{l}\text { Breusch-Pagan test of } \\
\text { independence }\left(\chi^{2}\right)\end{array}$ & & $10,583^{* * *}$ & \\
\hline
\end{tabular}

aThis study's data set excludes observations for the years 2008, 2009, and 2012.

Note: Asterisks $\left({ }^{*},{ }^{* *},{ }^{* *}\right)$ denote significance at the $10 \%, 5 \%$, and $1 \%$ levels, respectively.

loans packaged for refinancing. The Beg Farmer Dum result has an important implication as the FSA distinguishes itself from other farm lenders through its commitment to assist beginning farmers even when these borrowers may not fully satisfy the conventional business track record requirements usually imposed by commercial lenders.

Among the financial performance variables, loan amount decisions are influenced only by differences in borrowers' liquidity conditions (CR). Results 
suggest that repayment ability, financial efficiency, and leverage conditions do not significantly determine the amount of loan approved for direct loan borrowers.

\subsection{Loan Pricing}

The second equation analyzed effective interest rates that the borrower is actually charged. Among the demographic dummy variables, the significant coefficient results indicate that lenders' decisions on loan pricing may be influenced by racial and age factors. Non White Dum registered a significant positive coefficient, thereby establishing that nonwhite borrowers are charged higher interest rates than white borrowers. The compelling evidence in this equation is the insignificance of the gender variable (Female Dum), which implies that the borrower's gender is not an important consideration in decisions on setting interest rates. Moreover, loans obtained by older farmers carry higher interest rates.

Liquidity considerations remain as the only financial performance factor that significantly affects loan pricing decisions. Higher interest rates are also associated with borrowers outside the Beginning Farmer program as well as those taking out Farm Ownership loans.

\subsection{Loan Maturity}

The last equation analyzed the indicators of lending officers' loan maturity decisions, which represents the number of years given to borrowers to fully repay their loan obligations. The results suggest that racial and gender attributes are not significant considerations in the loan officers' decisions on loan maturity. The only significant demographic factor is age where older farm borrowers enjoy significantly longer loan maturities than younger borrowers. Liquidity and operating efficiency are significant financial performance factors for loan maturity decisions.

All three loan program variables produced significant coefficients. The trends indicate that shorter loan maturities are prescribed for beginning farmers, operating loan accounts, and credit accommodations packaged for refinancing purposes.

\section{Conclusions and Implications}

This study draws its motivation from historical lending discrimination claims of various minority borrower groups filed against the USDA in the 1990s. This study analyzes more recent trends in FSA guaranteed lending decisions to discern any changes and improvements in the servicing of loan requests of minority farmers. This analysis looks at comparative trends in and linkages between the borrowers' financial performance conditions and the FSA guaranteed loan terms packaged by commercial lenders for various racial and gender categories of borrowers. 
Results of statistical pairwise comparisons indicate that although loan amounts and maturities prescribed for certain racial and gender minority groups are statistically equivalent to those stipulated in loan contracts for other borrower categories, these borrowers, however, are charged significantly higher interest rates compared with rates approved by lending officers for other groups of similar loan size and terms. Among such disadvantaged groups, nonwhite male and female borrowers are usually charged higher interest rates than the others. White and nonwhite females, however, received equivalent average loan amounts at similar loan maturities. On average, male borrowers are able to obtain larger loan amounts at longer maturities but are charged higher interest rates.

Econometric results confirm most of the previously discussed trends. Using general racial category variables, the results indicate that nonwhite borrowers indeed are charged significantly higher interest rates for loans that are usually smaller compared with white borrowers' loan transactions. Although there are no significant differences noted in the repayment ability and other financial performance measures among the borrower classes, loan pricing decisions could apparently be determined by other credit risk factors not captured in this study's model.

Accounting for the terms of an approved credit accommodation, the results of this study thus contend that a typical nonwhite direct loan borrower would enjoy relatively the same loan maturity as his or her white counterpart that offers favorable repayment arrangements for his or her relatively lower loan amount even if the contracted interest rate is usually higher. As an earlier study on FSA lending decisions (Escalante et al., 2006) has established, the significance of the racial factor in loan approval decisions was attributed to the relatively higher credit risk profile of nonwhite farmer applicants. This current study further tracks down decisions of FSA lending officers throughout the lending process with a focus on racial considerations. Consistent with the 2006 study results on the racial factor, this analysis establishes that when loan applications are approved, further credit risk management strategies are employed whereby loan pricing, amount, and maturity decisions may be precipitated by variable borrower credit risk profiles that, in the case of this study, may be significantly differentiated by size and financial efficiency factors, among others (Table 1).

Consistent with a previous related study (Escalante, Epperson, and Raghunathan, 2009), this study's SUR results did not validate significant gender bias implications. Except for substantially larger loan amounts approved for male borrowers, the loan pricing and maturity equations did not produce any significant gender bias effect. Moreover, the estimation results validate the FSA's progress in assisting beginning farmers with their credit requirements. This study's results establish that the FSA has packaged loan accommodations for these farmers that bear lower interest rates for their relatively larger loan amounts, but carrying shorter maturities. The loan amount factor suggests the FSA's commitment to adequately support these farmers' funding requirements 
and further provides them with more affordable interest rates. However, the shorter maturity decision could be the lender's credit risk management strategy, which allows the lender to assist budding farmer entrepreneurs with promising business potential who are understandably assessed as relatively more risky borrowers than experienced, mature borrowing farm businesses. Through the relatively shorter FSA accommodation, these farmers are given the opportunity to quickly establish some track record that will eventually allow their businesses to mature and increase their competitive stance in procuring more business funding from regular lenders in the future.

Relating this study's results to the current state of FSA lending programs, it may be noted that the USDA has significantly augmented efforts in servicing the credit needs of its minority borrowers since the settlement of various lawsuits with several racial and gender minority groups in the late 1990s. In recent years, the USDA, under the leadership of Secretary Vilsack, has actually consciously and seriously adopted measures to implement what Vilsack refers to as "a new era of civil rights" (U.S. Government Accountability Office, 2012, p. 30). Promoting a zero tolerance for any form of discrimination, Vilsack launched a comprehensive program aimed at promoting greater fairness and more equitable delivery of services to the USDA's clientele. Among a number of initiatives, these efforts include review and settlement of pending civil cases, efficiently addressing clients' management challenges, proactive and reactive compliance reviews, training for the cultural transformation of USDA employees, improved outreach efforts, and the creation of a more diverse politically appointed workforce.

This study lends some support to the effectiveness of such institutional reform campaigns as the results clarify that only seemingly justifiable disparities have been validated in comparing loan term stipulations for various racial and gender classes. Specifically, the FSA's credit risk management strategy in loan pricing is mitigated by longer loan maturity and seemingly reasonable loan amount decisions. From the borrower's perspective, the combination of such trends in the loan term components could provide borrowers, especially those with less than ideal credit risk profiles, with opportunities to further improve their credit risk ratings in the future as they establish a business track record and further improve their business financial conditions. In recent years, the FSA's loan exposure to its SDA clients has been increasing. For instance, this portfolio registered an overall growth of $14 \%$ between 2014 and 2015 (NSAC, 2015). As more minority borrowers are accommodated by the FSA, these borrowers must take advantage of such opportunities to develop favorable repayment track records that in time could reverse even the more stringent loan pricing risk mitigating strategy of credit risk management employed by commercial lenders beyond the FSA lending paradigm. By then, minority borrowers can expect their loan terms to reflect their graduation to low-risk priority client status enjoying, among other things, favorable interest rates, within and beyond the FSA lending framework. 


\section{References}

Boehm, T.P., P.D. Thistle, and A. Schlottmann. "Rates and Race: An Analysis of Racial Disparities in Mortgage Rates." Housing Policy Debate 17,1(2006):109-49.

Cheng, P., Z. Lin, and Y. Liu. "Racial Discrepancy in Mortgage Interest Rates." Journal of Real Estate and Financial Economics 51,1(2015):101-20.

Chite, R.M. Appropriations for FY1999: U.S. Department of Agriculture and Related Agencies. CRS Report for Congress. Washington, DC: Congressional Research Service, 1998. Internet site: http://nationalaglawcenter.org/wp-content/uploads/assets/ crs/98-201.pdf (Accessed November 2017).

Escalante, C.L., R. Brooks, J.E. Epperson, and F.E. Stegelin. "Credit Risk Assessment and Racial Minority Lending at the Farm Service Agency." Journal of Agricultural and Applied Economics 38,1(2006):61-75.

Escalante, C.L., J.E. Epperson, and U. Raghunathan. "Gender Bias Claims in Farm Service Agency's Lending Decisions." Journal of Agricultural and Resource Economics 34,2(2009):332-49.

Feder, J., and T. Cowan. Garcia v. Vilsack: A Policy and Legal Analysis of a USDA Discrimination Case. Washington, DC: Congressional Research Service, 2013.

Fiebig, D.G. "Seemingly Unrelated Regression.” A Companion to Theoretical Econometrics. Blackwell Companions to Contemporary Economics. B.H. Baltagi, ed. Hoboken, NJ: Wiley, 2001, pp. 101-21.

Greene, W.H. Econometric Analysis. Upper Saddle River, NJ: Prentice Hall, 2012.

Gujarati, D., and D. Porter. Basic Econometrics. Columbus, OH: McGraw-Hill Education, 2006.

Hanson, G., W. Delavan, and L. Power. "Mandated Financial Training for FSA/USDA Farm Borrowers.” Journal of Extension 34,2(1996):2FEA3. Internet site: http://www.joe.org/ joe/1996april/a3.html (Accessed May 25, 2005).

Isidore, C. "Ally to Pay $\$ 98$ Million for Car Loan Bias." CNN Money. December 20, 2013. Internet site: http://money.cnn.com/2013/12/20/news/companies/ally-car-loandiscrimination/ (Accessed August 14, 2015).

Koenig, S., and C. Dodson. "FSA Credit Programs Target Minority Farmers." Agricultural Outlook 266(November 1999):14-16.

May, C. "Obama USDA Offering Women, Hispanic Farmers over \$1.3 Billion in Discrimination Payouts." Daily Caller. September 25, 2012. Internet site: http:// dailycaller.com/2012/09/25/obama-usda-offering-women-hispanic-farmers-over-1-3billion-in-discrimination-payouts/ (Accessed June 27, 2016).

Meyers, A.L. "Honda Will Pay \$24 Million for Overcharging Minorities." Christian Science Monitor. July 15, 2015. Internet site: http://www.csmonitor.com/Business/2015/ 0715/Honda-will-pay-24-million-for-overcharging-minorities (Accessed August 14, 2015).

Miller, L.H., and E.L. LaDue. "Credit Assessment Models for Farm Borrowers: A Logit Analysis.” Agricultural Finance Review 49(1989):22-36.

Moon, H.R., and B. Perron. "Seemingly Unrelated Regressions." The New Palgrave Dictionary of Economics. New York: Macmillan, 2006, pp. 1-9.

National Sustainable Agriculture Coalition (NSAC). "High Demands for Farm Loans in 2015 with Even Greater Demand on Horizon for 2016.” NASC’s Blog. November 13, 2015. Internet site: http://sustainableagriculture.net/blog/2015-fsa-loan-data/ (Accessed June 27, 2016). 
Savage, C. “Countrywide Will Settle a Bias Suit." New York Times. December 21, 2011. Internet site: http://www.nytimes.com/2011/12/22/business/us-settlement-reported-oncountrywide-lending.html (Accessed March 4, 2016).

- "Wells Fargo Will Settle Mortgage Bias Charges." New York Times. July 12, 2012. Internet site: http://www.nytimes.com/2012/07/13/business/wells-fargo-to-settlemortgage-discrimination-charges.html? $\mathrm{r}=0$ (Accessed March 4, 2016).

Splett, N.S., P.J. Barry, B.L. Dixon, and P.N. Ellinger. "A Joint Experience and Statistical Approach to Credit Scoring.” Agricultural Finance Review 54(1994):39-54.

Tedeshi, B. "Why Women Pay Higher Interest." New York Times. January 21, 2007. Internet site: http://www.nytimes.com/2007/01/21/realestate/21mort.html (Accessed August 14, 2015).

Turvey, C.G. "Credit Scoring for Agricultural Loans: A Review with Applications." Agricultural Finance Review 51(1991):43-54.

U.S. Department of Agriculture, Farm Service Agency (USDA-FSA). Creditworthiness Determinations. Washington, DC: USDA, FmHA AN No. 3199, 1995.

. Creditworthiness Determinations. Washington, DC: USDA, Notices FC-117 and FC142, 1997.

- FSA Handbook: Guaranteed Loan Making and Servicing. Washington, DC: USDA, 2016. Internet site: http://www.fsa.usda.gov/Internet/FSA_File/ 2flphandbook20120508.pdf (Accessed June 27, 2016).

U.S. Government Accountability Office (GAO). U.S. Department of Agriculture: Progress toward Implementing GAO's Civil Rights Recommendations. Washington, DC: U.S. Government Accountability Office, GAO-12-976R, 2012.

The White House. Affirmative Action Review. Washington, DC: Office of the President and the First Lady, the White House, 2000. Internet site: https://clinton4.nara.gov/WH/EOP/ OP/html/aa/aa11.html (Accessed March 4, 2016). 